\title{
SUBSTANTIAL RELATIONS
}





\section{SUBSTANTIAL RELATIONS}

Making Global Reproductive Medicine in Postcolonial India

\section{Sandra Bärnreuther}


Thanks to generous funding from the Swiss National Science Foundation, the ebook editions of this book are available as open access volumes through the Cornell Open initiative.

\section{Copyright ( 2021 by Cornell University}

The text of this book is licensed under a Creative Commons

Attribution-NonCommercial-NoDerivatives 4.0 International License: https://creativecommons.org/licenses/by-nc-nd/4.0/. To use this book, or parts of this book, in any way not covered by the license, please contact Cornell University Press, Sage House, 512 East State Street, Ithaca, New York 14850. Visit our website at cornellpress.cornell.edu.

First published 2021 by Cornell University Press

ISBN 978-1-5017-5819-5 (hardcover)

ISBN 978-1-5017-5820-1 (pdf)

ISBN 978-1-5017-5821-8 (epub)

Library of Congress Control Number: 2021944996

DOI: https://doi.org/10.7298/0rf-ds33

Chapter 1 was first published in Zeitschrift für Ethnologie 143:41-60 under the title "From Urine in India to Ampoules in Europe: The Relational Infrastructure of Human Chorionic Gonadotropin." An earlier version of chapter 2 appeared in the article "Innovations 'Out of Place': Controversies over IVF Beginnings in India between 1978 and 2005," Medical Anthropology 35 (1): 73-89, DOI: 10.1080/01459740.2015.1094066, https://www.tandfonline.com/. 
Für Cilli und Hans 
